\title{
The science behind the development and performance of reduced ignition propensity cigarettes
}

\author{
Richard R Baker, Steven Coburn, Chuan Liu* and Kevin G. McAdam
}

\begin{abstract}
A burning cigarette is a known cause of fire when mishandled. Studies into cigarette ignition propensity intensified after the US Cigarette Fire Safety Act of 1984. Extensive research has investigated the thermal properties of a smouldering cigarette, mostly away from any object of thermal contact or interference. To understand fire ignition, the thermophysics of cigarette's burning tip has also been examined with and without a contact substrate. In either free or contact smouldering cases, oxygen diffusion through the cigarette wrapping paper has been found to be an important parameter controlling the rate of burn and the energy released. Research by the US National Institute of Standards and Technology led to a standardized test method to determine cigarette ignition propensity, and eventually regulations enforcing Reduced Ignition Propensity (RIP) cigarettes have been passed in all US states and other countries. Among the physical parameters of a burning cigarette related to its thermal energy release, circumferential bands applied to the cigarette wrapping paper that reduce air permeability or diffusivity during smouldering have become the main approach to produce commercial RIP cigarettes. Studies have been performed to ensure that RIP cigarettes have equivalent or lower mainstream smoke yields and biological activities as compared with their conventional non-RIP equivalents. The effects of the paper band properties (width, gap between the bands, type as well as the amount of the material applied) have been studied systematically to establish a manufacturability window. Studies on human smoking behaviour confirmed that RIP cigarettes matched closely their predecessors. The bands, as intended, alter the combustion temperatures during cigarette smouldering within the band. Further research into the interaction of RIP cigarettes with different types of commercial upholstery fabrics and materials should help to understand its mechanism of action in support of emerging postimplementation fire statistics.
\end{abstract}

Keywords: Ignition propensity, Cigarette, Thermophysics, Combustion

\section{Background}

Dropped or improperly discarded, cigarettes may cause fire, and cigarette-related fire can lead to property losses, injuries and fatalities (Hall JR Jr, 2013; Ahrens 2011; Ahrens 2013). The extent of cigarette-related fires compared to fires started by other sources (e.g., electrical failures or cooking) has been documented in a few highincome countries. In the United States, for example, cigarette smoking accounted for $2 \%$ of residential fires, but $14 \%$ of all fire deaths in residential buildings according

\footnotetext{
*Correspondence: chuan_liu@bat.com

Deceased

GR\&D Centre, British American Tobacco, Regents Park Road, Southampton SO15 8TL, UK
}

\section{Springer}

C 2016 Baker et al. Open Access This article is distributed under the terms of the Creative Commons Attribution 4.0 International License (http://creativecommons.org/licenses/by/4.0/), which permits unrestricted use, distribution, and reproduction in any medium, provided you give appropriate credit to the original author(s) and the source, provide a link to the Creative Commons license, and indicate if changes were made.

one recent statistics (US Fire Administration 2012), and the US Fire Administration's efforts in tracking the fire statistics during which the research on reduced ignition cigarettes were being carried out goes back to many years.

For a burning cigarette to ignite a substrate (i.e., sustained smouldering and/or flame combustion of the substrate), three steps have to take place: first, thermal contact must occur between the cigarette and the substrate; second, there must be sufficiently high energy release from the cigarette so that the temperature of a localized area of the substrate is above its ignition temperature; and third, the localised smouldering has to propagate (Ohlemiller 1985; Drysdale 2011; Rein 2009; Salig 1982). 
The fundamental thermal properties of a burning cigarette have long been an active area of research (Egerton et al. 1963), mainly to further understanding of the formation and chemical composition of smoke (Baker 1981). The resulting knowledge is, however, intrinsically linked to the unintended consequence of a burning cigarette acting as an ignition source. Contact between the burning cigarette and the material is usually due to accidents or carelessness, as reflected in the fact that approximately $26 \%$ of residential smoking-related fires originate in the living rooms, family rooms and dens, not counting all residential categories (Hall JR Jr, 2013). This contributes to about $75 \%$ of the fire deaths.

To reduce the incidence of smoking-related fires, many European countries such as the United Kingdom, France, Ireland, Italy, Finland, Sweden, Norway, Spain and Portugal (Singh \& Jain 2009; Babrauskas et al. 2011; Guillame et al. 2008), have mandated that furniture fabrics must pass a standard test to ensure that they are resistant to a lit cigarette and a burning match, and this is normally achieved by treating furniture's cover fabric and/or supporting foam with flame retardants.

In the United States, an alternative emphasis has been to make cigarettes less likely to ignite (Howland \& Hingson 1987; Botkin 1988; Barillo et al. 2000; Leistikow et al. 2000; Gunja et al. 2002). Research into cigarette characteristics that might lead to reduced cigarette ignition propensity has been driven by the National Institute for Standards and Technology (NIST) in Washington DC (Gann et al. 1987; Brigham \& McGuire 1995), resulting in the establishment of a standardized laboratory method to measure cigarette ignition propensity (Ohlemiller et al. 1993; ASTM American Society of Testing Materials Standard E2187-04 2004 \& E2187-09 2009). In parallel, the US Upholstered Furniture Action Council (UFAC) adopted a voluntary testing and classification standard for cigarette ignition resistance of upholstered furniture and furniture components (National Fire Protection Association 1998). Extensive research in fire blocking technologies for soft furnishings has also been carried out (Nazaré and Davis 2012). The State of California recently revised its Technical Bulletin 117, which outlines a flammability testing method as of January 1, 2014 which allows furniture and upholstery manufacturers to test smoulder resistance of cover fabrics, barrier materials, resilient filling materials, and decking materials for use in upholstered furniture (State of California Department of Consumer Affairs 2014).

The aim of this review is to discuss (i) research fundamental to understanding the smouldering behaviour of cigarettes, (ii) the scientific research behind the development of a standardized test method for measuring ignition propensity, and (iii) efforts to develop lower or reduced ignition propensity (RIP) cigarettes. Initial consumer behaviour studies on using RIP cigarettes and biological testings comparing potential biological differences between conventional and RIP cigarettes are also reviewed. Indications by fire statistics from some jurisdictions since the implementation of RIP regulation were briefly covered.

\section{Early research into cigarette ignition propensity}

The fundamental thermal properties of a burning cigarette have long been studied in an attempt to understand the formation and chemical composition of smoke. As described below, however, the resulting knowledge is intrinsically linked to the propensity of cigarettes to act an ignition source.

\section{Basic thermal properties of cigarettes}

Once lit, a cigarette assumes two alternating modes of burn: static smouldering, when it is not puffed; and forced smouldering, when it is actively puffed. The peak puffing temperature of the burning tip (termed the "coal") depends on the puff flow rate, typically $\sim 850-950{ }^{\circ} \mathrm{C}$ around the coal's peripheral surface (Baker 1975). When considering a cigarette as an ignition source, it is the average peripheral static smouldering temperature (typically $\sim 650-700{ }^{\circ} \mathrm{C}$ (Baker 1975; Lendvay \& Laszlo 1974; McRae et al. 1987; Liu \& Woodcock 2002), the temperature distribution around the burning coal, and the rate and/or manner of temperature movement that need to be evaluated.

Combustion of tobacco in a cigarette is not complete (Baker, 1999). Studies based on calorimetry have determined the heat of complete combustion of various different tobaccos as $13.8-18.4 \mathrm{~kJ} / \mathrm{g}$ in oxygen (Gugan 1966; Muramatsu et al. 1978; Norman et al. 2001). These values directly correlate with the carbon and hydrogen contents of the tobacco materials. Although tobaccos are richer in nitrogen content than most other types of biomass, this high nitrogen content does not alter the trend set by carbon and hydrogen contents.

The heat generated from a smouldering cigarette has been reported as 4.6-6.7 kJ/g from measurements of $\mathrm{CO}, \mathrm{CO}_{2}$ and $\mathrm{H}_{2} \mathrm{O}$ and differential scanning calorimetry (Muramatsu et al. 1978; Muramatsu 1981); 6.6-8.3 kJ/g from radiative heat emission (Ihrig et al. 1986); 8-10 kJ/ $\mathrm{g}$ from cone calorimeter (Robinson et al. 1992); $7.5 \mathrm{~kJ} / \mathrm{g}$ from the total heat output of a smouldering cigarette (Waymack et al. 1997; Miura et al. 2001); and $7.8 \mathrm{~kJ} / \mathrm{g}$ from heat emitted by radiation and convection (Miura 2001). These values, which are broadly in agreement, indicate that a static smouldering cigarette emits about half the heat of complete combustion of an equivalent amount of tobacco.

Miura et al. (2001) further revealed that, during smouldering, almost half of the energy is emitted by radiation and the remainder by convection (caused by buoyancy 
around the coal) - a ratio that is relatively independent of the smoulder burn rate. The thermal emissivity of the cigarette burning zone during smoulder is $0.87-0.88$ (Lyman et al. 2003), which is somewhat less than would be expected from a char produced from a biomass fuel. This may be because the surface of the burnt tobacco rod is usually covered with a layer of cigarette paper that is rich in calcium carbonate and its residual decomposition product (Zheng et al. 2006).

If a smouldering cigarette is placed on a substrate at room temperature, there will be an initial reduction in the cigarette's burning temperature before the substrate is sufficiently heated to influence their combined subsequent thermal behaviour. The fate of the cigarette and the substrate will depend on the thermal interaction between them and the surrounding environment. The cigarette's burning temperature and heat output, surface contact, thickness and properties of the tobacco ash, air flow, properties of the substrate material, and formation and transfer of volatile species are some of the factors that may influence the ignitability (Babrauskas \& Peacock 1992).

Ignition temperature is defined as the maximum surface temperature of the material upon fire inception. This value is only approximate because it depends on the dynamics of the fire initiation (Williams 1976). The maximum surface temperature of a cigarette during smoulder $\left(\sim 650{ }^{\circ} \mathrm{C}\right)$ is greater than the ignition temperature of most common furniture cover materials. Because not all fabrics are ignited by smouldering cigarettes, other factors besides reaching the ignition temperature must also be important in determining ignition; some of which will be discussed in the next section. The ignition temperatures of some common natural or synthetic polymer materials are shown in Table 1 (Ihrig et al. 1986; Hedges et al. 1978; Ohlemiller \& Rogers 1980; Ohlemiller 1981; Gandhi 1998).

The interior of a cigarette's burning zone is highly oxygen-deficient (Baker 1999; Baker 2006), hence an oxygen concentration gradient exists across the cigarette paper close to the burning zone (Gugan 1966). Part of the oxygen is also carried round the front of the burning

Table 1 Ignition temperature of common household materials (generic names as they are commonly used, does not representing the classification of the materials involved)

\begin{tabular}{ll}
\hline Material & Ignition temperature \\
\hline Cellulosics & $220-400{ }^{\circ} \mathrm{C}$ \\
PVC & $\sim 260{ }^{\circ} \mathrm{C}$ \\
Polyethylene & $\sim 390{ }^{\circ} \mathrm{C}$ \\
Mylar & $440-480{ }^{\circ} \mathrm{C}$ \\
Nylon & $450-500{ }^{\circ} \mathrm{C}$ \\
Polyurethane & $\sim 500{ }^{\circ} \mathrm{C}$ \\
\hline
\end{tabular}

zone in the natural convection stream. Baker (1984) proposed that the rate of diffusion of oxygen through the paper has a direct influence on the cigarette smoulder rate, $\mathrm{S}\left(\mathrm{mg} \mathrm{s}^{-1}\right)$ :

$$
\mathrm{S}=\mathrm{a}+\mathrm{bD}
$$

where $\mathrm{D}$ is the diffusion coefficient of oxygen in air through the cigarette paper $\left(\mathrm{cm}^{2} \mathrm{~s}^{-1}\right)$, a is a constant related to the transfer of oxygen to the burning zone, and $\mathrm{b}$ is a constant related to the area of paper through which diffusion can occur. Both a and $\mathrm{b}$ are likely to depend on properties of the tobacco bed, paper properties, area of paper exposed to air, and physical position of the cigarette on a substrate. For naturally porous cigarette papers, the air permeability (a commonly measured paper parameter under a defined pressure difference (Norman 1999; International Standard Organisation 2009)) and gaseous diffusion coefficient are linked by the following relationship (Baker \& Crellin 1977; Baker \& Robinson 1994):

$$
\mathrm{D}_{\mathrm{p}}=1.58 \times 10^{-3} \sqrt{\mathrm{Z}}
$$

where $D_{p}$ is diffusion coefficient through the paper $\left(\mathrm{cm} \mathrm{s}^{-1}\right)$, and $\mathrm{Z}$ is the paper permeability $\left(\mathrm{cm} \mathrm{min}^{-1}\right.$ $\left.\mathrm{kPa}^{-1}\right)$. The square root relationship in this equation can be rationalized theoretically by the paper behaving as a series of pores whose diameter is much less than the paper thickness (Baker \& Crellin 1977).

The studies reviewed in this section have defined a burning cigarette's average thermophysical properties as those of a smouldering biomass rod with a peak temperature of $c a$. 600 to $700{ }^{\circ} \mathrm{C}$, extending over a volume of $8 \mathrm{~mm}$ diameter and a length of $1-2 \mathrm{~cm}$ (for a standard king-size cigarette of $c a .8 \mathrm{~mm}$ diameter), moving at a rate of $2-5 \mathrm{~mm}$ per minute as it burns through a $58 \mathrm{~mm}$ long tobacco section. Combined with its component material properties in controlling oxygen availability, a smouldering cigarette may then act to produce smoke when puffed or behave as an ignition source when brought in contact with another object.

\section{Factors affecting cigarette and substrate interaction}

Fabric and substrate parameters

Notably, between 1975 and 1982 the annual rate of residential fires in the United States appeared to correlate with the annual rate of cigarette consumption and the average ignitability of chairs in use (Yea 1985). Heavy weight fabrics seemed to show a higher ignition response to lit cigarettes than lighter weight fabrics (Damant et al. 1983; Damant 1995; McCormack et al. 1988; Donaldson et al. 1983; Gandhi \& Spivak 1996). These types of results led to the belief that a standard test 
method might be developed to mimic the interaction between a furniture fabric cover or its mock-up and a smouldering cigarette (Gann et al. 1987; Ohlemiller et al. 1993).

Regardless of the lack of a standard test, early studies examining the fabric-cigarette interaction found that there is a correlation among the thermal characteristics of the burning cigarette, the total sodium and potassium content of the fabric, the mass of the fabric near the cigarette burning zone, and the extent of oxygen diffusion through the fabric to the cigarette burning zone (Wu et al. 1992; Dwyer et al. 1994; Lewis et al. 1995a, 1995b; Kellogg et al. 1998; Spears et al. 1995). These factors agree with the understanding that smouldering ignition is affected by the degree to which the total system is adiabatic. The time and heat flux required for the initiation of smouldering was also found to depend on the environment and the properties of the fabric (Kellogg et al. 1998; Yi et al 2001). However, different results were obtained by different test laboratories as to the degree of correlation with cigarette type, and up to three quarter of the 79 upholstery fabrics produced similar ranking with the cotton duck fabrics used (Greear et al. 1996; Eberhardt et al. 1997; Hirschler 1997a, 1997b; Wanna \& Zelius 2001; Wanna \& Chen 2001; Ihrig et al. 1987). Taken together, these studies highlight the technical difficulties in developing a fabric-based standard method due to the specification and production of reproducible batches of test fabrics.

\section{Cigarette parameters}

Studies conducted by the Center for Fire Research (National Bureau of Standards, Washington DC) identified a number of key cigarette parameters that influenced the outcome of the test (Gann et al. 1987; Krasny et al. 1989). The studies used a series of 32 cigarettes in which the design variables were systematically varied but in many cases departed from the realm of commercially acceptable cigarettes for the purpose of establish any observable trend. The following five cigarette design parameters were varied at two levels: tobacco blend (burley vs flue-cured tobacco), tobacco packing density (expanded vs non-expanded tobacco), cigarette paper air permeability (10 vs 70 CORESTA units; a CORESTA unit is defined as the volumetric air flow $\left(\mathrm{cm}^{3} \mathrm{~min}^{-1}\right)$ passing through $1 \mathrm{~cm}^{2}$ of test material at an applied pressure of $1.00 \mathrm{kPa}$ ), cigarette paper burn additive $(0.7 \%$ citrate vs no additive) and cigarette circumference ( $25 \mathrm{vs} 21 \mathrm{~mm}$ ). In terms of reducing the ignition propensity, the studies identified the following factors (Gann et al. 1987; Krasny et al. 1989).

- Reduced tobacco packing density was the most important factor. Reducing the amount of tobacco led to less tobacco available for fuel per unit length of the cigarette. In practical terms, however, the tobacco rod has to have a certain density to ensure its physical integrity. However, tobacco density can be decreased to some extent by expanding the structure of the cut tobacco strands or by cutting tobacco shreds wider (Norman 1999; Nakanishi 1999).

- Reduced paper permeability was the next most important factor, because it decreases the amount of oxygen that can diffuse through the paper during smoulder (Norman 1999). At the time of the study, paper permeability was thought to be the main factor that controls oxygen diffusion; however, this was later corrected to paper diffusivity (Norman et al. 2005). Reduced paper permeability is now known to increase mainstream smoke emissions from a cigarette, and hence, can be deployed only to a limited extent.

- Decreased cigarette circumference was also considered important because it reduces the tobacco available to burn, as well as the contact zone between the substrate and the cigarette. This may also be reflected by the lack of differentiation in mock-up RIP tests between slim and standard diameter cigarettes (Lewis et al. 1993a, 1993b). The reduced heat flux per unit volume of the substrate for slim cigarettes may be behind variations in experimental results.

- Removal or reduction in levels of cigarette paper burn additives was found to have a variable effect on ignition. In addition, unfiltered cigarettes are found to have a higher tendency in ignition than filtered cigarettes and filter lengths were also found to influence the ignition outcome (Gann et al. 1987; Harwood et al. 1993).

\section{ASTM standard E2187}

In the 1990s, findings from the above studies led NIST to consider that it might be possible to establish a standardized laboratory method to measure cigarette ignition propensity, and initially two candidate methods were evaluated (Ohlemiller et al. 1993; Ohlemiller et al. 1995): a "direct" and an "indirect" method.

The "direct" method involved furniture mock-ups with cotton duck fabrics over foam blocks (Fig. 1). The method provided a vehicle for assessing cigarette ignition propensity, and the ignition and sustained smoulder of some cotton duck substrates were occasionally observed when tested by this method. The "indirect" method involved 3, 10, or 15 layers of filter papers (the type of ash-free cellulose filter paper normally used in a chemistry laboratory to separate solids from liquids), and examined a cigarette's tendency to sustained smoulder. The extinction probabilities of a test cigarette found in the indirect method were shown to correlate 

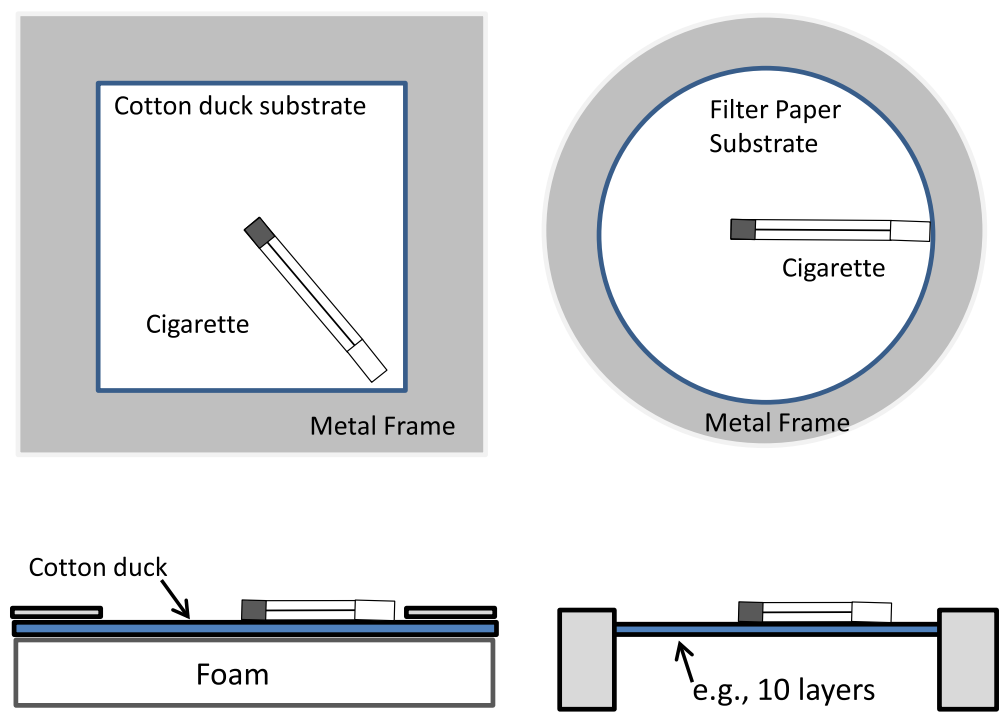

filter paper

Fig. 1 Schematic illustration of the 'direct (left)' and 'indirect (right)' methods proposed by NIST (Ohlemiller et al. 1993)

with the results from the direct method. Figure 1 illustrates the principle differences between the direct and indirect methods.

As described above, the challenge was to demonstrate that a laboratory approach could be standardized with acceptable tolerance. Although furniture covers are usually fabrics, some are synthetic and some are cellulosic-based materials, for various practical and technical reasons (Lewis et al. 1990; Lewis et al. 1993a, 1993b; Lewis et al. 1995a, 1995b; Jupe et al. 1995; Wanna et al. 1996), the direct method with a cotton duck fabric was not pursued because of unavailability of the material. The indirect method was finally adopted by the American Society of Testing Materials (ASTM) as its standard (E2187-02b; hereafter E2187) (ASTM American Society of Testing Materials Standard E2187-04 2004 \& E2187-09 2009).

\section{Approaches to reduced ignition propensity cigarettes}

Producing a RIP cigarette poses a number of challenges. For example, consumers expect that a cigarette, when being used as intended, will stay alight when not actively puffed and will deliver the anticipated sensory experience. In addition, regulations must be met regarding the chemical composition of the mainstream smoke (Borgerding \& Klus 2005). Furthermore, the demands of modern manufacturing present a significant technical challenge for commercial cigarettes with RIP.

Given these requirements, the most common approach to produce a RIP cigarette has been to add material on to the wrapping paper in the form of bands, including hatched, zigzagged or spiral bands, around the circumference of the cigarette (Ihrig \& Zawadzki 2002; Seaman
1933). Notably, many of the methods used to produce these bands in some earlier patents employed materials that would not pass current standards of toxicology such as asbestos, polyvinyl chloride and silicates.

Banding is usually achieved by printing a polymer (e.g., alginate or cellulosic polymers) in a water or solvent mixture onto one side of the paper during paper manufacturing. After drying or solvent evaporation, the added material forms an additional layer on the base paper surface to block portions of the fine pores that are responsible for gas diffusion (Eitzinger 2006a, 2006b). Under scanning electron microscope, a banded surface (Fig. 2, right) may appear to be smoother and the fibre veins are less visible, consistent with the presence of a coating. The extent of visual difference under microscopy may not correlate with the band material's performance in blocking gas diffusion, which depends on the properties and amount of the material applied during paper making. The square root relationship between the diffusion coefficient and permeability, derived above (equation 2), has to be tested to show that it remains valid for the banded region, because its derivation was justified theoretically by the paper behaving as a series of pores whose diameter is much less than the paper thickness (Baker \& Crellin 1977).

In 2000, Merit brand cigarettes with a patented banded paper were put on test-marketing in the United States by Philip Morris. Subsequently, NIST compared the ignition propensity performance of the cigarette with banded paper against a conventional version of the same cigarette by both the direct cotton duck method and the indirect filter paper method (Gann et al. 2001). Relative to its conventional counterpart, the test cigarette with the banded paper was found to have a lower number of 


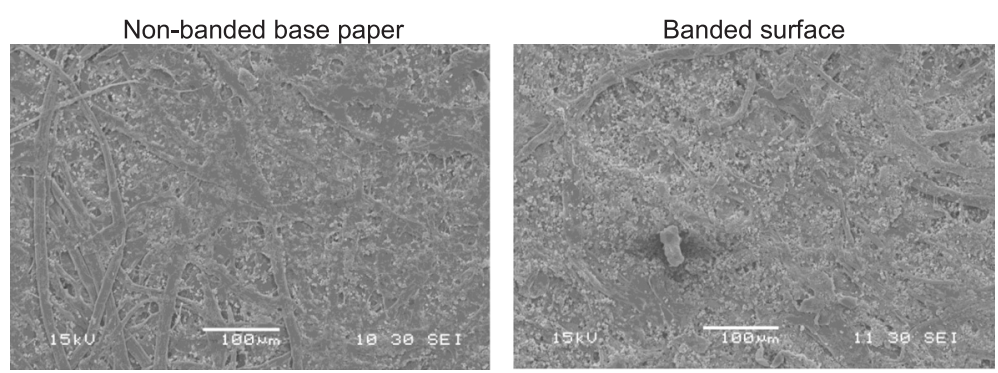

Fig. 2 Surface morphology of a cigarette paper before (left) and after (right) the band was applied

ignitions on three types of cotton duck fabric, and lower numbers of full-length burns on 3,10 or 15 layers of filter paper. These findings supported the use of banded paper as a tool to reduce the ignition propensity of a cigarette, as defined by the ASTM E2187 standard method, and also demonstrated that one major manufacturer and its paper supplier had the technology and capability for commercial production.

Aspects of the research and engineering modifications behind the development of banded paper cigarettes were first presented at the CORESTA Congress in 2000 and 2001 (Garg et al. 2001; Watkins \& Jones 2001; Watkins et al. 2001a; Watkins et al. 2001b). This development involved the application of highly refined cellulosic material bands on the cigarette paper during the production process. Adequate control of fibre size through refining, band width, and air permeability were considered critical to ensure consistent ignition performance.

A preliminary study in the United Kingdom supported NIST's finding of a correlation between cigarettes that pass the indirect method and their reduced propensity to initiate fire in standard furniture mock-ups (Paul 2000). It also proposed that the introduction of cigarettes with reduced ignition power as a possible alternative to cigarette-resistant furniture composites, as defined by UK regulation (BSI 1324 Schedule 4 of 1988 and the 1980 regulations), may not give the same reduction in cigarette risk and hence the existing policy of requiring ignitionresistant furniture composites should be maintained.

Studies to understand the thermal behaviour of cigarettes with banded paper have shown that the bands act to reduce the diffusion of oxygen through the paper to the back of the burning zone of a smouldering cigarette (Watkins \& Jones 2001; Watkins et al. 2001a; Watkins et al. 2001b). This in turn reduces the coal's temperature and the amount of heat generated, such that the cigarette is more prone to extinguishing in the ignition propensity tests. NMR imaging along the length of a smouldering cigarette revealed that the paper bands also act to suppress the outward diffusion of volatile species as sidestream smoke plume (Watkins et al. 2001a, 2001b), possibly adding an additional thermal burden to the coal.
The development of the ASTM E2187 standard was built on a partial understanding of the thermal processes involved in ignition by a smouldering cigarette, and the compromises inherent in its utility to mimic real-life situations of fire initiation. The emergence of banded cigarette paper on a commercial scale galvanised the adoption of this standard test method. Arguably, the availability of a commercial RIP solution has had the effect of diluting research efforts toward understanding the mechanisms involved in the ignition of upholstery fabrics and furniture by smouldering cigarettes which predated the two U.S. programs (1984-1987) and (1990-1993).

In a recent report summarising a study conducted by U.S. Consumer Product Safety Commission, Division of Combustion and Fire Sciences (Mehta 2012), it concluded that "Further analysis indicates that differences between the ignition propensity of RIP and non-RIP cigarettes, when measured on filter paper substrates per ASTM E2187-04, do not predict similar differences between the ignition propensity of the same packaging of RIP and non-RIP cigarettes when measured on the mattress and mattress pad substrates included in this study. Whether a cigarette - RIP or non-RIP - burned its full length or extinguished before burning its full length was not predictive of smouldering behaviour on the substrates. In addition, RIP cigarettes of different packaging did not exhibit the same results on each of the mattress and mattress pad substrates brands."

\section{Research in the post-E2187 era}

Since 28 June 2004, all cigarettes sold in New York State have had to pass an ignition performance criterion, which must be tested via the ASTM E2187 standard method. As a result, almost all data published on ignition propensity since 2004 have focused on aspects of the ASTM test method, as well as the cigarette designs and cigarette material properties needed to meet this standard.

\section{Research from the tobacco industry}

Since the publication of ASTM E2187, numerous studies by tobacco manufacturers and their suppliers have been presented at the industry's annual research conferences that cover cigarette design, the RIP test method and 
mechanistic studies. These studies are not peerreviewed, although the conference materials are available (CORESTA and Tobacco Science Research Conference; www.coresta.org). For example, establishing a practical operational window between the paper band permeability and the pass/FASE rate (Fig. 3) has been highlighted as one of the key considerations for manufacturability. Below the main technical themes of the industry research have been summarised, with key findings listed in Table 2.

The impact of these issues individually on the test outcomes may be relatively minor; in other words, they are unlikely to change the ranking order of banded and non-banded cigarettes. Collectively, however, they contribute to the total variability of the test method and potential difficulties for regulatory enforcement. Efforts are continuously made to improve the consistency and integrity of the test method by the relevant standardization authorities (ASTM and more recently ISO).

\section{Banded RIP cigarette performance Diffusion through the band or paper}

The importance of oxygen diffusion into the burning zone and in controlling steady-state smouldering of cellulosic materials is well known (Moussa et al. 1977). The mechanism of oxygen diffusion through a solid membrane with a microscopic structure (e.g., a cigarette paper) differs from the mechanism of air flow due to a pressure difference (Baker and Crellin 1977). The former is driven by the oxygen concentration gradient and tortuosity of the microscopic pores within the structure, whereas the latter is controlled by forced air flow (pressure difference) and dominated by the presence of large pores or holes. These two properties coexist in RIP cigarette paper and in combination control both the mainstream smoke yields during puffing and reduced ignition propensity during the RIP test (Norman 1999; Norman et al. 2005).

As mentioned above, banding is achieved by printing a polymer onto one side of the paper. The added material block portions of the fine pores on the base paper surface that are responsible for gas diffusion (Eitzinger 2006a, 2006b). For conventional non-banded cigarettes, oxygen transfer through the cigarette paper occurs during puffing and smouldering mainly through the semi-charred cigarette paper (Miura 2001; Eitzinger \& Giener 2008), probably because gas permeability increases exponentially when paper is subjected to thermal degradation (Baker 1976). However, the mechanism by which the band material affects oxygen diffusion has not been fully established.

Two mechanisms seem most likely (Fig. 4): in the first, the band controls room-temperature oxygen diffusion; in the second, the modified band/base paper affects oxygen diffusion characteristics after a certain degree of thermal decomposition. Because a reasonable correlation between the room temperature diffusion coefficients and RIP performance have been demonstrated, the band may effectively limit oxygen availability long before the approaching burning coal. Smoke deposition on the inside surface of the cigarette paper during smouldering has also been hypothesized, but not proven, to affect oxygen diffusion.

An analysis of cigarettes that "pass" the RIP test (i.e., greater than $75 \%$ of the test cigarettes that extinguish before burning to the tipping paper, usually set by a regulator) to establish the location of extinguishment in relation to the band may help to understand the dominant mechanism. This is illustrated in Fig. 4, case A represents extinguishment of the test cigarette significantly ahead of the band, possibly caused by the cigarette coal being in contact with the substrate alone with virtually no influence of the band; in cases $B$ and $C$, the band plays a role in the extinguishment but affects the advanced restriction to oxygen availability to different extents. In case $\mathrm{D}$, however, the cigarette extinguishes immediately after passing through the band; it is likely that the band still plays its role in suppressing the smouldering tendency of the burning coal. A failed RIP cigarette using the banding technology is therefore a cigarette that its bands are not sufficient to achieve either of the four situations described and the cigarette continue to burn the end of its tobacco column.

Drake et al. (1980) proposed the principle of measuring the diffusion coefficient of gases through cigarette paper, whereby the paper is sandwiched and sealed between an upper and a lower gas chamber, in which laminar flow of the gas mixtures are carefully controlled (Fig. 5). Concentration differences in carbon dioxide (higher in the lower chamber) drive the gas diffusion into the upper $\mathrm{N}_{2}$ chamber. As the test gases moves from the inlets (left) to the outlets (right), further diffusion and mixing occurs which is governed by the paper layer inbetween. Numerous research and commercial instruments have been devised based on this principle (Miura 2001) and diffusivity values have become a specification parameter for the banded region. Further experimental studies to elucidate the mechanism played by oxygen diffusion may be beneficial to examine the steady-state interaction between a smouldering cigarette and a substrate in situ as specified in ASTM E2187.

\section{Computer modelling}

Mathematical modelling of a burning cigarette has the potential to simulate the main thermal physical and chemical processes that occur as it is smoked (Baker 2006; Muramatsu et al. 1979; Muramatsu 2005); however, development of an effective method has proved to 
Table 2 Research findings from the tobacco industry (www.coresta.org) Factors affecting operation or accuracy of ASTM E2187 test outcomes

A smouldering cigarette may burn close to the cigarette tipping paper (the paper wrapper connecting the filter with the tobacco rod). When this occurs, the operator has to make a subjective judgment on whether the test piece has "passed" or "failed" the test, because the paper char line may display a gradient of charring across $\geq 1 \mathrm{~mm}$.

The cigarette paper that wraps the tobacco rod has a longitudinal seam. Its orientation relative to the contact point with the substrate may affect test results because the seamed region has different gas diffusion and/ or heat conduction properties. The standard test methodaccommodates this by specifying that all test cigarettes must have their seams facing upward during the test.

Test results depend on the "side" (i.e. surface roughness) of the substrate paper (Whatman No. 2 filter paper). Simply specifying "Whatman No. 2 filter paper" is also not sufficient to guarantee test performance because systematic differences in the test results were observed when Whatman relocated its production site.

Prototype automatic or semi-automatic test machines have been designed to improve the efficiency and consistency of the test.

Band parameters and effects

Band diffusivity values have become the most important band specification parameter. Commercial instruments have been designed to allow both the air permeability and diffusivity of the band to be determined with good accuracy. The band width is usually 5-7 mm, spaced between 16 and $20 \mathrm{~mm}$ apart, and invisible to the naked eye. These values are derived through systematic experiments and/or computer modelling. The position of the bands are randomly distributed along the length of the tobacco rod, but usually two complete bands are present for a 57- $\mathrm{mm}$ tobacco rod (the most common format of cigarettes) (Codwise et al. 2006; Eitzinger 2006a, 2006b; Eitzinger 2008)

Thermophysical studies on a steady-state smouldering cigarette in a 10-layer filter paper test noted that there was a significantly modified temperature distribution inside the burning coal of the banded cigarette. The top three layers suffered severe thermal decomposition around the contact region with the burning coal, and overall the substrate acted essentially as a heat sink with no intrinsic sustained smouldering or flame combustion.

\section{Correlations with other cigarette measurements}

The free-air self-extinguishment (FASE) rate is the percentage of cigarettes that go out during free smouldering. Free smouldering is defined as a smouldering cigarette that burns without intermittent puffs applied to it. FASE follows a relationship opposite to that of band permeability to control the RIP "pass rate" based on $75 \%$ of test pieces extinguish before reaching their full length (Fig. 3). Studies have shown that a band permeability of 10-15 CORESTA units $\left(\mathrm{cm}^{3} \mathrm{~min}^{-1} \mathrm{kPa}^{-1}\right)$ statistically satisfies both RIP performance and an acceptable FASE rate. An air permeability window of 5 CORESTA units has to be carefully controlled to ensure that different tobacco blends are accommodated to meet the RIP target. This value also needs to be coordinated with properties of the base paper to maintain set mainstream smoke yields.

A correlation exists between percentage full-length burn measurement obtained during the standard RIP test and the mean burn length (the average tobacco rod length burnt during the RIP test) — a relationship that helps to evaluate the effect of cigarette design parameters for those cigarettes that consistently achieve a "pass rate" of $100 \%$.

Other studies

In addition to the ignition propensity regulation, RIP cigarettes have to meet existing regulations on smoke yields. For example, all cigarettes sold in the European Union have to meet the limits of $10 \mathrm{mg}$ of tar, $1 \mathrm{mg}$ of nicotine and $10 \mathrm{mg}$ of carbon monoxide in mainstream smoke, as measured by International Organization for Standardization (ISO)
Table 2 Research findings from the tobacco industry (www.coresta.org) (Continued)

standard machine-smoking parameters (ISO3308 2012). To mitigate the impact of adding bands on the cigarette paper, which restricts oxygen availability and increases the amount of organic material to burn during a puff, cigarette manufacturers usually make systematic adjustments to the base paper properties and/or tobacco blend compositions.

Different statistical approaches and uncertainties have been associated with some of the short-term (e.g., 1- or 2-year) fire statistics reported since the introduction of RIP regulation.

be a major challenge owing to the complexity of the process and a general lack of mechanistic and kinetic information (Ohlemiller 1985; Eitzinger \& Pirker 2005). Assumptions and simplifications have been made to derive a working model that represents the main processes involved and keeps the targeted smoke chemistry and thermal physics in mind.

As reviewed by Muramatsu (2005), early modelling work mainly focused on understanding and predicting smoke formation and smoke composition. Subsequently, one-dimensional to three-dimensional models of a free smouldering cigarette with and without puffing, or a smouldering cigarette with a substrate combination have all been attempted (Ohlemiller et al. 1993; Eitzinger 2006a, 2006b; Eitzinger \& Pirker 2005; Mitler \& Walton 1993; Saidi et al. 2006).

For example, Eitzinger and Pirker (2005) described a computational fluid dynamic model of a free smouldering cigarette, and attempted to mathematically induce contact between the smouldering cigarette and the 10layer filter paper substrate as defined in ASTM E2187. Their free-smouldering model predicted that both a reduced variation of cigarette parameters and the appropriate choice of oxygen diffusion coefficient are equally important in designing cigarette papers for reduced ignition propensity. However, the non-steady-state transient contact between the smouldering cigarette and the substrate proved to be too difficult to solve mathematically. A percentage of test cigarettes are always extinguished during this initial transient contact with the substrate, and further research is needed to understand the mechanism involved in this non-steady-state phenomenon.

Eitzinger (2006a, 2006b) developed a simpler onedimensional computer model of a smouldering cigarette to examine the effects of many cigarette parameters, including tobacco density, tobacco heat capacity, width of the band and the diffusion coefficient of oxygen through the paper, on the self-extinguishing properties of the cigarette. All of the parameters were assumed to be independently normally distributed. The model found that a high oxygen diffusion coefficient through the bands will prevent the cigarette from extinguishing even during smouldering on a substrate. On the other hand, too low an oxygen diffusion coefficient will lead to self- 


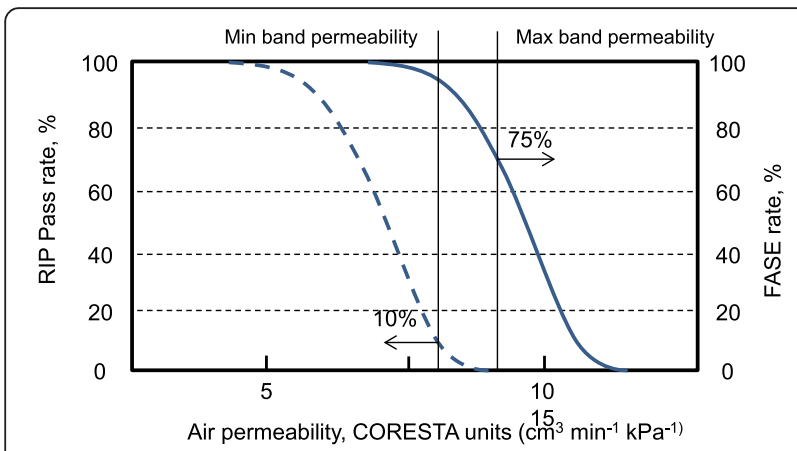

Fig. 3 The practical range of band air permeability lies between $>75 \%$ compliance and $<10 \%$ free-air self-extinguishment (FASE) rates

extinguishing during free smoulder. The region between these two limits gave a diffusion coefficient of 0.13 to $0.23 \mathrm{~cm} \mathrm{~s}^{-1}$ for the modelled situation. The range of this value narrowed even further when the statistical variations of the cigarette parameters were included. The model further predicted that the tobacco heat of combustion and the width of the paper bands have a pronounced effect on the cigarette's self-extinguishing ability. Below a width of about $1.5 \mathrm{~mm}$, the cigarette would not extinguish in the ASTM test even if the oxygen diffusion coefficient through the band were reduced to zero. A width of more than $5 \mathrm{~mm}$ would be needed for the cigarette to extinguish during the ASTM test; this agrees well with current experience as most commercial RIP cigarettes have bands of 6-7 $\mathrm{mm}$.

More sophisticated 3-dimensional, time-dependent models of a free smouldering cigarette, or a smouldering cigarette placed on a flat substrate (e.g. a fabric placed over a polyurethane foam) have also been established (Ohlemiller et al. 1993; Mitler \& Walton 1993; Saidi et al. 2006). These models have addressed the relative importance of oxygen supply to the cigarette burning zone via two other paths: first, from ambient air above the fabric; and second, from ambient air contained within the polyurethane foam below the fabric. These two oxygen transfer paths may be more important in real fire initiation than in the configuration defined by the ASTM E2187 standard. As stated above, however, the overall degree of success achieved by these models is limited owing to a lack of mechanistic and kinetic information (Ohlemiller 1985), and useful predictive models of realistic fire hazard situations remain lacking.

Empirical statistics-based models have also been used to analyse the effects of a cigarette's physical properties on its ignition propensity (Hirschler 1997a, 1997b). In the early NIST studies (Gann et al. 1987), the decrease in ignition propensity observed with reduced cigarette circumference was thought to be due to a lower mass burn rate of tobacco, leading to a lower total heat transfer from the cigarette to the fabric substrate, and the decrease in ignition propensity with reduced paper permeability was thought to be due to decreased oxygen diffusion through the paper to sustain smouldering. Good predictions of these NIST results as a function of cigarette physical parameters were achieved with empirical statistics-based models.

With commercial RIP cigarettes becoming the dominant products available in most North America and Europe countries as demanded by regulations (Gann 2007; European Committee for Standardization CEN, 2010;Timmis 2007), further computer modelling and thermal analyses could be used to understand the ignition mechanism of the RIP cigarettes in combination with a variety of fabric materials.

\section{Effect of the band on mainstream smoke yields}

Shortly after the New York regulation was passed, the levels of 22 toxicants in mainstream smoke from four cigarette brands from New York and Massachusetts were measured under ISO-equivalent machine-smoking conditions (Connolly et al. 2005). According to the study, fourteen of the smoke constituents were the same; however, $\mathrm{CO}$ yields were increased $7 \%-16 \%$ in the New York brands, naphthalene yields were increased $9 \%-22 \%$ in the New York brands and five other polycyclic aromatic hydrocarbon (PAHs) were also higher (4 \%-14 \%) in the New York brands, although the statistical significance of these values may need to be examined further due to limitations of current analytical methodology. The authors concluded that the introduction of RIP cigarettes had no effect on consumer purchase patterns of

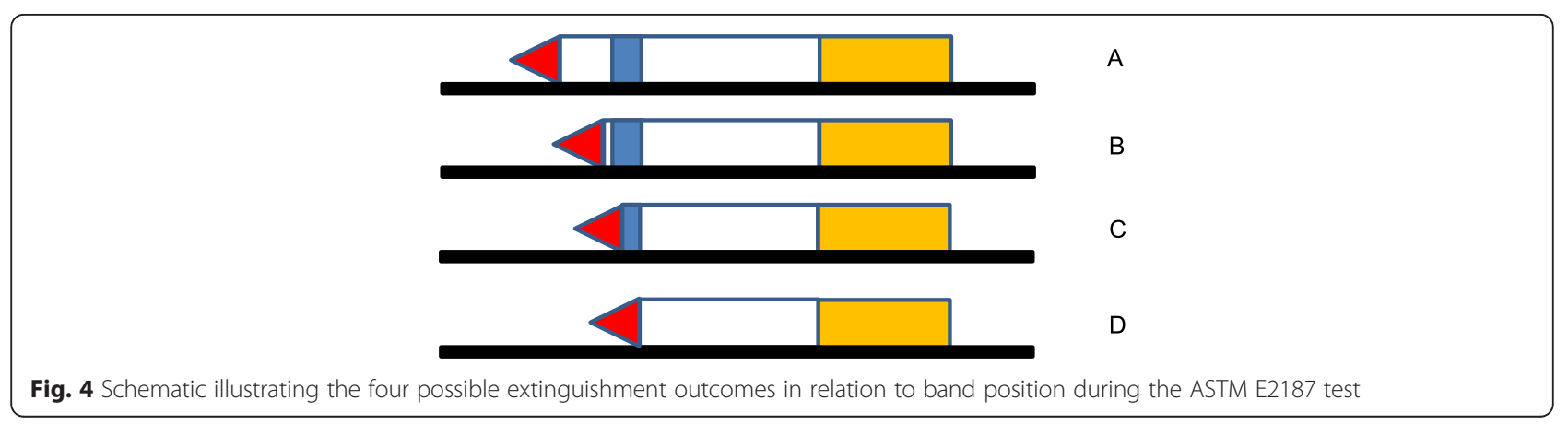




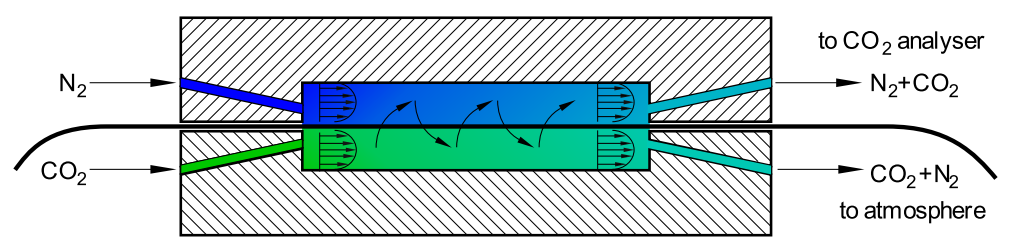

Fig. 5 The principle behind diffusion coefficient measurement across a cigarette paper (drawing courtesy of Dr Bernhard Eitzinger)

cigarettes in New York. In other words, the altered design of these brands did not significantly influence consumer choice.

It also is unknown whether the increases in standard smoking machine yields of these compounds have any biological relevance. Humans smoke their cigarettes differently from a standard smoking machine (Borgerding \& Klus 2005); thus, smoking topography (i.e., total puff volume, puff count, puff velocity, duration of puff and puff interval) would be a more appropriate method to estimate any possible change in smoking behaviour (Pauly et al. 2009; Mariner \& Shepperd 2011).

The various toxicants in mainstream smoke are formed by distinct physical and chemical processes (Baker 2006; Piadé et al. 2013), which may be altered differentially (i.e. increased or decreased) by modifications in the RIP cigarette design. With the advancement in online mass spectrometry techniques for smoke analyses (Mitschke et al. 2005; Adam et al. 2009; Bachmann et al. 2012), in situ gas-phase analysis coupled with thermal physical methods may prove to be a powerful tool to understand the smoke chemistry properties of RIP cigarettes in fire initiation situations.

\section{Effect of the band on cigarette combustion}

In comparison to the number of studies examining the smouldering behaviour of banded cigarettes, few studies have been published on how the band may affect the puffing burn behaviour of the cigarette. Sherwood et al. (2006) measured and compared the radiant coal power, $\mathrm{P}(\mathrm{t})$, between banded and non-banded cigarettes during free smouldering:

$$
P(t)=\sigma \varepsilon A \sum_{i}^{i=k} T_{i}^{4}(t)
$$

where $\sigma$ is the Stefan-Boltzmann constant, $\varepsilon$ is the radiative emissivity of the burning coal, $A$ is the area associated with the pixel size of the infrared camera used in the experiment, $k$ is the number of pixels, and $T_{i}(t)$ is the temperature of the $i^{\text {th }}$ pixel. Histograms generated from 40 cigarettes showed that the band shifted the distribution of the radiant power to lower values. Individual measurements revealed that the free smouldering radiant power of the coal started to decrease $\sim 50 \mathrm{~s}$ before the paper char line reached the band.

In a recent study ( $\mathrm{Li}$ et al. 2014), gas-phase combustion temperatures of a burning cigarette around the RIP band regions were measured by using fine thermocouples. Standard ISO puffing was applied when the cigarette burn line moved to the left edge of the RIP band. Figure 6, which displays the situation at $1 \mathrm{~s}$ (the peak flow rate of the $35 \mathrm{~mL}$ puff) into a 2-s puff, shows that the internal temperature contours of the banded and non-banded cigarettes clearly differ. The temperature gradient contours reflect the speed at which the temperature changes, and may be linked to the availability of oxygen at the local region (assuming that the difference in heat release rate is negligible). For conventional cigarettes, the highest air influx during the puff (Fig. 6, right, black arrows) occurs around the peripheral region just ahead of the burn char line (Baker 1999). The higher temperature gradient regions inside the RIP cigarette (Fig. 6, left) are more centrally located, indicating that the highest air influx may be forced towards the tip of the burning cone by the presence of the band.

Li et al. (2014) also observed that the internal free smouldering gas-phase temperatures start to decrease $\sim 20 \mathrm{~s}$ before the paper char line reaches the band; a trend similar to that observed for the radiant power measurement. The extent of changes in combustion temperature may not be surprising given the large difference in air permeability between the banded and nonbanded region. Further research is needed to ascertain whether or not this modified combustion behaviour leads to changes in the mainstream smoke chemistry, or indeed is linked to reported increases in mainstream smoke polycyclic aromatic hydrocarbon (PAH) emissions (Harris 1992).

\section{Toxicology and smoking behaviour}

Modifications to cigarette designs to reduce ignition propensity may have unintended consequences, for example, on smoke chemistry and toxicological properties (Harris 1992; Brunnemann et al. 1994; Alpert et al. 2005). An earlier study concluded that lower ignition propensity cigarettes could be made while still retaining acceptable smoke yields and activity in an in vitro Ames test (Harris 1992). Recent studies comparing commercial 


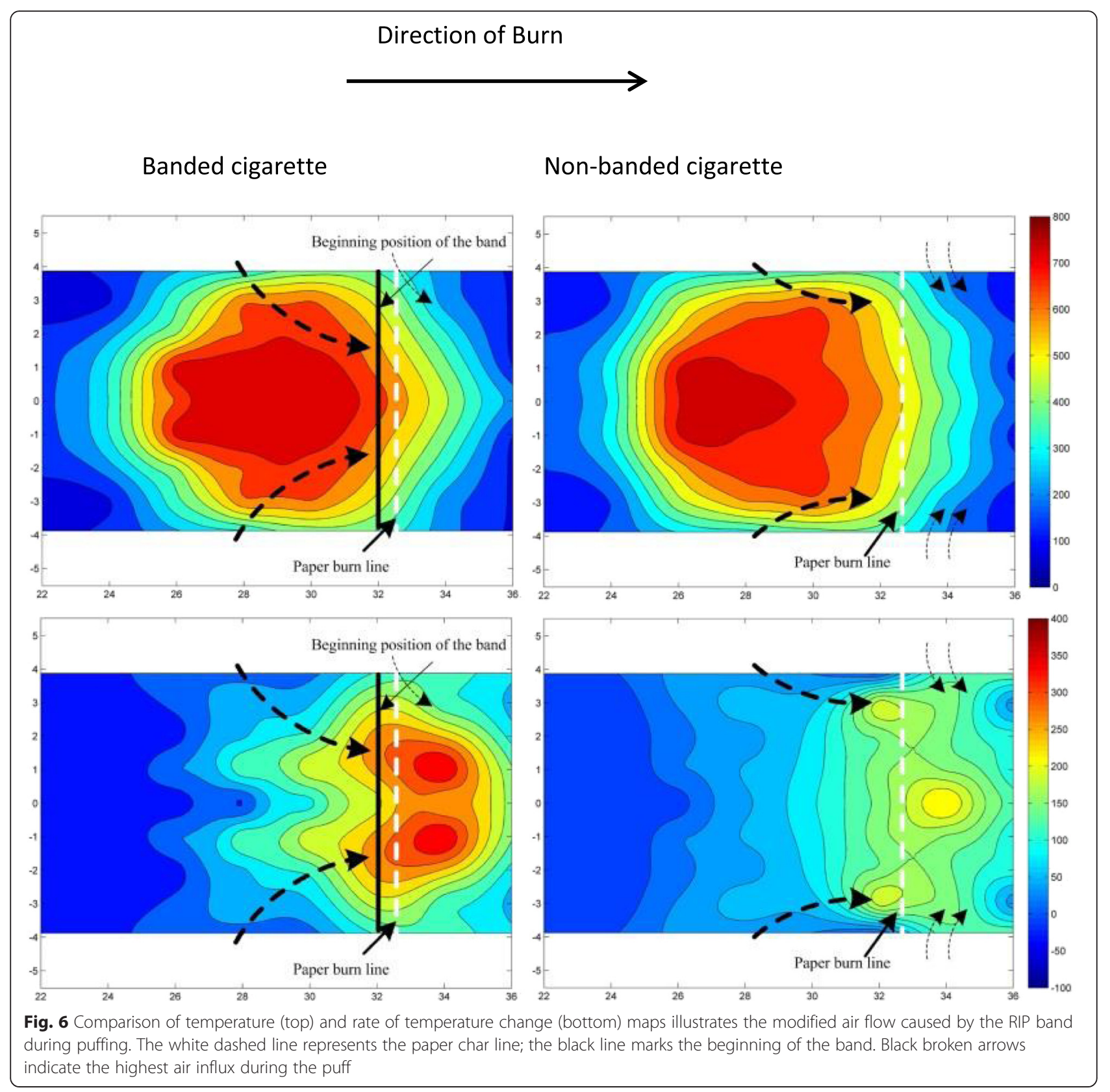

and experimental RIP cigarettes using both in vitro toxicological assays and animal models found that there were no significant differences between the products (Theophilus et al. 2007a; Theophilus et al. 2007b; Werley et al. 2013).

As described above, initial consumer awareness evaluations shortly after the introduction of legislation in New York found no measurable effect on consumer purchasing or smoking habits (Connolly et al. 2005; Ruegg \& Petraglia 2005; O'Connor et al. 2006; O'Connor et al. 2010). However, New York smokers were three times more likely than smokers in other states to report that their cigarettes went out between puffs ( $17.3 \%$ vs $5.6 \%)$.
Studies among smokers in Canada have generally found that RIP cigarettes did not lead to alterations in either cigarette consumption or smoking topography (June et al. 2011; Côté et al. 2011), although there was a significant increase (14.3 to $23.5 \%$ ) in smokers' exposure to three PAH biomarkers.

On 25 June 2013, the Center for Tobacco Products of the US Food and Drug Administration issued two Technical Project Lead Memoranda (SE0003730 and SE0003731) approving Newport brand non-menthol Gold Box and Gold Box 100 s. The memoranda stated that the key differences between the modified products and their respective predecessors were the absence of 
menthol, the presence of fire standard compliant (RIP) cigarette paper and changes to design features to maintain the consistency of smoke delivery. The memoranda concluded that "the new product does not raise different questions of public health."

\section{Fire statistics since the implementation of RIP regulation}

The test method in the ASTM E2187 standard represents a simplified fire initiation scenario as compared with the multitude of possibilities of real-life fire initiation (Ahrens 2011; Ahrens 2013). Although general theoretical models of fire ignition have been developed and modelled, incorporating the complex physics of heat and mass transfer, the chemistry of solid-phase decomposition and gas-phase runaway reactions (Atreya 1998; Lautenberger \& Fernandez-Pello 2009), their practical application to predict fire ignition outcome remains challenging owing to the absence of the many pyrolysis kinetic and chemical reaction details in these models (Babrauskas 2007). More than a decade has passed since New York introduced RIP regulation, there have been a number of evaluations of fire incidence statistics post RIP regulation in part of the United States that had the RIP law (Seidenberg et al. 2011; Frazier et al 2011; Hall 2013; Yau and Marshall 2014; Alpert et al. 2014). They found from significant reductions in fire incidences, up to $40 \%$ as compared to the pre-implementation period, to no observable effect with the RIP technology. In a recent laboratory study conducted by U.S. Consumer Product Safety Commission (CPSC), Division of Combustion and Fire Sciences (Mehta 2012; Mehta 2013), a range of factors such as whether using RIP or non-RIP cigarettes, burned its full length or extinguished before burning its full length, were all found to be an ineffective predictor of smouldering behaviour on furniture upholstery substrates. This reflects the current limitations in our knowledge to bridge complex real-life fire initiations, to using different fabrics/ substrates in laboratory studies, and to the simplified cellulose paper based ASTM2187-09 standard test method. Regulators and those involved in fire prevention should still be cautious to rely on the RIP technology as the single or the main measures for fire prevention. The true effect of the RIP cigarettes can only be verified by real-life fire statistics from multiple jurisdictions with different cultural or social background.

\section{Conclusion}

As a simplified standard method, the ASTM2187 should not be taken as the end-all solution to solve cigarette related fire risks. To address a smouldering cigarette as a fire source and upholstery material as an ignition target, current research proves that controlling oxygen diffusion into the burning coal is effective and directly related to the reduction of its heat influx to the surrounding environment. Extensive body of work has been done to establish a design window for a burning cigarette from sensory, smoke chemistry and smoke biological activity point of view, but still deliver reduced heat flux once in contact with a substrate. This technical approach does not take into account of the substrate's composition and physical shape, both of which have proved to influence the fire initiation to a significant extent. With commercial RIP cigarettes currently sold in many jurisdictions implementing the RIP regulations, early fire statistical data give a mixed picture on the effectiveness of the RIP cigarettes in reducing real-life fire incidence, from up to $40 \%$ of reduction in fire incidence to no significant effect. Importantly, it has shown no reported negative impact on fire risks so far. Fundamental research into the thermal physical interaction between RIP cigarettes and different substrate materials is still required to understand the effectiveness or the lack of it. The research outcome should also help to explore whether improved or alternative technology may become available. With smouldering cigarette - substrate systems sufficiently characterised, it is feasible that computer modelling may be deployed to simulate main fire initiation probabilities and highlight further opportunities to manage this risk. Regulators and fire prevention initiatives should continue their proven effective measures such as fire hazard education, fire alarm installation, fire escape route planning, etc, in addition to the implementation of RIP cigarette regulation.

\section{Abbreviations \\ ASTM: American Society for Testing Materials; BSI: British Standards Institute; CORESTA: Cooperation Centre for Scientific Research Relative to Tobacco; EU: European Union; FASE: free-air self-extinguishment; FCTC: framework Convention on Tobacco Control; FLB: full length burn (in percentage); ISO: International Organization for Standardization; NIST: National Institute of Standards and Technology; PAH: Polycyclic aromatic hydrocarbon; RIP: Reduced ignition propensity; WHO: World Health Organization.}

\section{Competing interests}

The authors declare no conflict of interests.

\section{Authors' contributions}

RRB instigated the work in 2007. The rest of the authors contributed equally by updating the contents since then. All authors read and approved the final manuscript.

\section{Acknowledgements}

The authors thank Dr B. Etizinger and Dr J. Wanna for useful discussions and the reviewers of the manuscript for constructive comments.

Received: 25 March 2015 Accepted: 26 February 2016

Published online: 14 March 2016

References

Adam T, Mitschke S, Baker RR, Zimmermann R (2009) Investigation of tobacco pyrolysis gases and puff-by-puff resolved cigrette smoke by single photon ionisation (SPI)-time-of-flight mass spectrometry (TOFMS). Beitrage zur Tabakforch Int 23:203-226 
Ahrens M (2011) Home fires that began with upholstered furniture. National Fire Protection Association, Quincy

Ahrens M (2013) Home structure fires. National Fire Protection Association, Quincy Alpert HR, Christiani DC, Orav EJ, Dockery DW, Connolly GN (2014) Effectiveness of the cigarette ignition propensity standard in preventing unintentional residential fires in Massachusetts. Am J Pulic Health 104:e56-61

Alpert HR, Carpenter C, Connolly GN, Rees V, Wayne GF (2005) The effect of the New York State cigarette fire safety standard on ignition propensity, smoke toxicity, and the consumer market. Harvard School of Public Health/ American Legacy Foundation

ASTM (American Society of Testing Materials) Standard E2187-04 (2004) \& E2187-09 (2009) Standard test method for measuring the ignition strength of cigarettes. ASTM International, West Conshohocken

Atreya A (1998) Ignition of fires. Phil Trans R Soc Lond A 356:2787-2813

Bachmann S, Gleinser M, Mohring D, Rohregger I, Volgger D (2012) Puff-by-puff analysis of mainstream smoke constituents of non-LIP/FSC and LIP/FSC cigarettes. CORESTA Congress, Sapporo. Smoke Science/Product Technology Groups, Abstr. PT16

Baker RR (1975) Temperature variation within a cigarette combustion coal during the smoking cycle. High Temp Sci 7:236-247

Baker RR (1976) Variation of the permeability of paper with temperature. Tappi 59:114-115

Baker RR, Crellin RA (1977) The diffusion of carbon monoxide out of cigarettes. Beitr Tabakforsch 9:131-140

Baker RR (1981) Product formation mechanisms inside a burning cigarette. Prog Energy Comb Sci 7:135-53

Baker RR (1984) The effect of ventilation on cigarette combustion mechanisms. Rec Adv Tob Sci 10:88-150

Baker RR, Robinson DP (1994) Semi-theoretical model for the prediction of smoke deliveries. In: Proceedings of CORESTA Congress, Harare, Zimbabwe, October 1994. Smoke and Technology Groups, p 63-72

Baker RR (1999) Smoke chemistry, in: Tobacco: Production, Chemistry and Technology, ed. D.L. Davis, M.T. Nielsen, Blackwell Science, CORESTA, p398-439

Baker RR (2006) Smoke generation inside a burning cigarette: modifying combustion to develop cigarettes that may be less hazardous to health. Prog Energy Comb Sci 32:373-385

Babrauskas V, Peacock RD (1992) Heat release rate: the single most important variable in fire hazard. Fire Safety J 18:255-272

Babrauskas V (2007) Ignition: a century of research and an assessment of our current status. J Fire Prot Eng 17:165-183

Babrauskas V, Blum A, Daley R, Birnbaum L (2011) Flame retardants in furniture foam: benefits and risks. Fire Safety Sci 10:265-278

Barillo DJ, Brigham PA, Kayden DA, Heck RT, McManus AT (2000) The fire-safe cigarette: a burn prevention tool. J Burn Care Rehab 21:164-170

Borgerding M, Klus H (2005) Analysis of complex mixtures-cigarette smoke. Exp Toxicol Pathol 57:43-73

Botkin JR (1988) The fire-safe cigarette. J Am Med Assoc 260:226-229

Brigham PA, McGuire A (1995) Progress towards a fire-safe cigarette. J Pub Health Policy 16:433-439

Brunnemann KD, Hoffmann D, Gairola CG, Lee BC (1994) Low ignition propensity cigarettes: smoke analysis for carcinogens and testing for mutagenic activity of the smoke particulate matter. Food Chem Toxicol 32:917-922

Codwise B, Durocher D, Wanna J (2006) Application of ISO 2965 (Section 4) to the permeability measurement of paper for lowered ignition strength cigarettes. CORESTA Congress, Paris: Smoke Science/Product Technology Groups, Abstr. PT14

Connolly GN, Alpert HR, Rees V, Carpenter C, Wayne GF, Vallone D et al (2005) Effect of New York State cigarette fire safety standard on ignition propensity, smoke constituents, and the consumer market. Tob Control 14:321-327

Côté F, Létourneau C, Mullard G, Vosine R (2011) Estimation of nicotine and tar yields from human-smoked cigarettes before and after the implementation of the cigarette ignition propensity regulation in Canada. Regul Toxicol Pharmacol S61:S51-S59

Damant GH, Williams SS, McCormack JA (1983) The role of fabric in the cigarette ignitions of upholstered furniture. J Fire Sci 1:309-321

Damant GH (1995) Cigarette ignition of upholstered furniture. J Fire Sci 13:337-349

Donaldson DJ, Yeadon DA, Harper RJ Jr (1983) Smoldering phenomenon associated with cotton. Textile Res J 53:60-64

Drake DG, Riley DS, Baker RR, Kilburn KD (1980) On a cell to measure diffusion coefficients of gases through cigarette papers. Int J Heat Mass Transfer 23:127-134
Drysdale D (2011) An Introduction to Fire Dynamics, 3rd edn. John Wiley \& Sons, New York

Dwyer RW, Fournier LG, Lewis LS, Furin D, Ihrig AM, Smith S et al (1994) The effects of upholstery fabrics properties on fabric ignitabilities by smoldering cigarettes. J Fire Sci 12:268-283

Eberhardt KR, Levenson MS, Gann RG (1997) Fabrics for testing the ignition propensity of cigarettes. Fire Mats 21:259-264

Egerton A, Gugan K, Weinberg FJ (1963) The mechanism of smouldering in cigarettes. Combust Flame 7:63-78

Eitzinger BS, Pirker S (2005) Numerical simulation of a cigarette during smoking. Beitr Tabakforsch Int 21:402-416

Eitzinger B (2006) An improved model of the porous structure of cigarette paper. CORESTA, Paris Congress, Abstr. PT07

Eitzinger B (2006b) A simulation study of self-extinguishing cigarettes. Beitr Tabakforsch Int 22:79-87

Eitzinger B (2008) Design guidelines for papers for low ignition propensity cigarettes. CORESTA Congress, Kyoto, Abstr. PT09

Eitzinger B, Giener H (2008) The effect of thermal decomposition of banded cigarette paper on ignition strength test results. CORESTA Congress, Shanghai, Abstr. SSPT23

European Committee for Standardization (CEN) (2010) Cigarettes - Assessment of the ignition propensity - Safety requirement. CEN standard EN 16156:2010

Frazier P, Schaenman P, Jones E (2011) Initial evaluation of the effectiveness of reduced ignition propensity cigarettes in reducing cigarette-ignited fires: case studies of the North American experience. TriData Division, System Planning Corporation, Arlington

Hall JR (Jr) (2013) The Smoking-Material Fire Problem. Quincy, MA: National Fire Protection Association

Harris J (1992) Overview and major considerations in the toxicity testing of low ignition-potential cigarettes. Report of Expert Panel to CPSC. Bethesda, MD USA: Consumer Product Safety Commission < available from http://legacy. library.ucsf.edu/>

Harwood B, Kissinger TL, Karter Jr MJ, Miller AL, Fahy RF, Hall Jr. et al. (1993) Cigarette fire incident study. Report No. 4, Technical Advisory Group, Fire Safe Cigarette Act of 1990. Gaithersburg, MD, USA: NIST

Hedges JD, Baer AD, Ryan NW (1978) Pyrolysis and ignition of polymers under approximated fire conditions, Proceedings of the Seventeenth Symposium (International) on Combustion. The Combustion Institute, Pittsburgh, pp 1173-1181

Hirschler MM (1997a) Comparison of the propensity of cigarettes to ignite upholstered furniture fabrics and cotton ducks (500-fabric study). Fire Mats 2:123-141

Hirschler MM (1997b) Mathematical models to analyse the effect of physical properties of cigarettes on the propensity of the cigarette to ignite cellulosic fabrics. Fire Mats 21:33-39

Howland J, Hingson R (1987) Alcohol as a risk factor for injuries or death due to fires and burns: review of the literature. Public Health Rep 102:475-483

Ihrig AM, Rhyne AL, Norman V, Spears AW (1986) Factors involved in the ignition of cellulosic upholstery fabrics by cigarettes. J Fire Sci 4:237-260

Ihrig AM, Rhyne AL, Spears AW (1987) Influence of flexible polyurethane foams on upholstery fabric foam mock-ups ignition by cigarettes. J Fire Sci 5:392-415

Ihrig AM, Zawadzki M (2002) An historical overview of cigarette ignition propensity research and patents. Pro Int Fire Saf 34:146-173

International Standard Organisation (2009) ISO 2965: Materials used as cigarette papers, filter plug wrap and filter joining paper, including materials having a discrete or oriented permeable zone and materials with bands of differing permeability-Determination of air permeability. Geneva

International Organization for Standardization. ISO 3308 (2012) Routine analytical cigarette-smoking machine-Definitions and standard conditions. Geneva: ISO; Geneva

June KM, Hammond D, Sjodin A, Li Z, Romanoff L, O'Connor RJ (2011) Cigarette ignition propensity, smoking behaviour, and toxicant exposure: a natural experiment in Canada. Tob Induc Dis 9:13-19

Jupe R, Shipley DK, Hudson WZ, Wanna JT, Greear LC (1995) Inter-bolt variability of cotton duck \#4 and the effects on cigarette ignition propensity test outcome. J Fire Sci 13:127-140

Kellogg DS, Waymack BE, McRae DD, Chen P, Dwyer RW (1998) The initiation of smoldering combustion in cellulosic fabrics. J Fire Sci 16:105-124

Krasny JR, Harris RH Jr, Levine RS, Gann RG (1989) Cigarettes with low propensity to ignite soft furnishings. J Fire Sci 7:251-288 
Gandhi S (1998) A study of smoldering conditions in upholstery fabrics using thermal imaging. Text Res J 68:687-696

Gandhi S, Spivak SM (1996) Comments on cigarette ignition of upholstered furniture. J Fire Sci 14:87-90

Gann RG, Harris RH Jr, Krasny JF, Levine RS, Mitler HE, Ohlemiller TJ (1987) The effect of cigarette characteristics on the ignition of soft furnishings. Report No. 3 of Technical Study Group on Cigarette and Little Cigar Fire Safety, Cigarette Safety Act of 1984 and NBS Technical Note 1241. US National Bureau of Standards, Gaithersburg

Gann RG, Steckler KD, Ruitberg S, Guthrie WF, Levenson MS (2001) Relative ignition propensity of test market cigarettes. NIST Technical Note 1436. Gaithersburg, MD, USA: NIST

Gann RG (2007) Measuring the ignition propensity of cigarettes. International Interflam Conference, 11th Proceedings. Volume 1. September 3-5, London, England, p145-155

Garg R, Reynolds, B, Phan T (2001) The development of banded cigarette paper to reduce fabric ignition propensity. Bull. Spec. CORESTA, Lisbon Congress, p194, Abstr. T4

Greear LA, Hudson WZ, Jupe R, Pinion D, Wanna JT (1996) Ignition responses of fifty upholstery fabrics to commercial cigarettes. J. Fire Sci 14:413-425

Gugan K (1966) Natural smoulder in cigarettes. Combust Flame 10:161-164

Guillame E, Chivas C, Sainrat, A (2008) Regulatory issues and flame retardant usage in upholstered furniture in Europe (Report). Fire Behaviour Division. $p$ 38-48. <http://www.see.ed.ac.uk/FIRESEAT/files08/04-Guillaume.pdf>. Accessed 1 March 2016.

Gunja M, Wayne GF, Landman A, Connolly G, McGuire A (2002) The case for fire safe cigarettes made through industry documents. Tobacco Contr 11:346-353

Lautenberger C, Fernandez-Pello C (2009) Generalized pyrolysis model for combustible solids. Fire Saf J 44:819-839

Leistikow BN, Martin DC, Milano CE (2000) Fire Injuries, Disasters, and Costs from Cigarettes and Cigarette Lights: A Global Overview. Prev Med 31:91-99

Lendvay AT, Laszlo TS (1974) Cigarette peak coal temperature measurements. Beitr Tabakforsch 7:276-281

Lewis LS, Townsend DE, Robinson AL (1990) A comparative ignition propensity study of foreign and U.S. cigarettes. J Fire Sci 8:239-253

Lewis LS, Townsend DE, Gee JW (1993) A comparative ignition propensity study of foreign cigarettes: an update. Paper presented at International Conference on Fire Safety, San Francisco, CA, USA

Lewis LS, Nestor TB, Gee JW, Morton MJ, Townsend DE (1993b) The effect of cigarette circumference on ignition propensity. J Fire Sci 11:52-65

Lewis LS, Morton MJ, Norman V, Ihrig AM, Fhyne AL (1995a) The effects of upholstery fabrics properties on fabric ignitabilities by smoldering cigarettes II. J Fire Sci 13:445-471

Lewis LS, Nestor TB, Townsend DE (1995b) A comparative ignition propensity study of foreign and U.S. cigarettes using the NIST cotton duck mockup ignition test method. J Fire Sci 13:386-398

Li B, Pang HR, Xing J, Wang B, Liu C, McAdam KG, Xie JP (2014) Effect of reduced ignition propensity paper bands on cigarette burning temperatures. Thermochim Acta 579:93-99

Liu C, Woodcock D (2002) Observing the peripheral burning of cigarettes by an infrared technique. Beitr Tabakforsch Int 20:257-264

Lyman CS, Perfetti TA, Riggs DM, Morgan WT (2003) Thermal emissivity and cigarette coal temperature during smolder. Beitr Tabakforsch Int 20:381-388

Mariner D, Shepperd I (2011) Regulatory Toxicol Pharmacol 61(3):S1-S65

McCormack JA, Damant GH, Hilado CJ (1988) Flammability studies of 700 articles of upholstered furniture. J Fire Sci 6:121-138

Mehta S (2012) Cigarette Ignition Risk Project. US Consumer Product Safety Commission, Washington DC

McRae DD, Jenkins RW Jr, Brenzier JS (1987) Measurement of temperature distribution of cigarette coals by infra-red imaging radiometry. In Proceedings of the International Conference on the Physical and Chemical Processes occurring in a Burning Cigarette. RJ Reynolds Tobacco Co., Winston-Salem, USA

Mitler HE, Walton GN (1993) Modelling the ignition of soft furnishings by a cigarette. NIST Special Publication 852. Gaithersburg, MD, USA: NIST

Mitschke S, Adam T, Streibel T, Baker RR, Zimmermann R (2005) Application of time-of-flight mass spectrometry with laser-based photoionization methods for time-resolved on-line analysis of mainstream cigarette smoke. Anal Chem 77:2288-2296

Miura K, Nagao A, Ueyama K (2001) Heat emission from a burning cigarette. Beitr Tabakforsch Int 19:245-249
Miura K (2001) Oxygen diffusion through cigarette paper. Beitr Tabakforsch Int 19:205-208

Moussa NA, Toong TY, Garris CA (1977) Mechanism of smoldering of cellulosic materials. Symp Combust 16:1447-1457

Muramatsu M, Umemura S, Okada T (1978) Consumption of oxygen and heat evolved during natural smoulder of a cigarette. J Chem Soc Japan 10:1441-1448

Muramatsu M, Umemura S, Okada T (1979) A mathematical model of evaporation-pyrolysis processes inside a naturally smoldering cigarette. Combust Flame 36:245-262

Muramatsu M (1981) Studies on the transport phenomena in naturally smouldering cigarettes. Scientific Papers of the Central Research Institute, Japan Tobacco and Salt Monopoly Corporation 123:9-77

Muramatsu M (2005) An approach to modelling a burning cigarette. Beitr Tabakforsch Int 21:286-293

Nakanishi Y (1999) Physical properties of leaf tobacco, in: Tobacco: Production, Chemistry and Technology, ed. D.L. Davis, M.T. Nielsen, Blackwell Science, CORESTA, p313-319

Nazaré S, Davis RD (2012) A review of fire blocking technologies for soft furnishings. Fire Sci Reviews 1:1-23

National Fire Protection Association (1998) NFPA 260: Standard Methods of Tests and Classification System for Cigarette Ignition Resistance of Components of Upholstered Furniture, Cincinnati, $\mathrm{OH}$

Norman A (1999) Cigarette design and materials. In: Davis DL, Nielsen MT (eds) Tobacco: Production, Chemistry and Technology. Blackwell Science, Oxford, pp 353-387

Norman AB, Perfetti TA, Perfetti PF, Hayworth RG (2001) The heat of combustion of tobacco and carbon oxide formation. Beitr Tabakforsch Int 19:297-308

Norman AB, Caudle JS, Henderson CW (2005) Measurement of gas diffusion capacity of cigarette papers. Beitr Tabakforsch Int 21:425-434

Ohlemiller TJ, Rogers RE (1980) Cellulosic insulation material, II, Effect of additives on some smolder characteristics. Combust Sci Technol 24:139-152

Ohlemiller TJ (1981) Cellulosic insulation material, III, Effects of heat flow geometry on smolder initiation. Combust Sci Technol 25:89-105

Ohlemiller TJ (1985) Modelling of smoldering combustion propagation. Prog Energy Combustion Sci 11:277-310

Ohlemiller TJ, Villa KM, Braun E, Eberhardt KR, Harris Jr. RH, Lawson JR, et al. (1993) Test methods for quantifying the propensity of cigarettes to ignite soft furnishings. Report No. 2, Technical Advisory Group, Fire Safe Cigarette Act of 1990 and NIST Special Publication 851. Gaithersburg, MD, USA; NIST

Ohlemiller TJ, Villa KM, Braun E, Eberhardt KR, Harris RH Jr, Lawson JR et al (1995) Quantifying the ignition propensity of cigarettes. Fire Mats 19:155-169

O'Connor RJ, Giovino GA, Fix BV, Hyland A, Hammond D, Fong GT et al (2006) Smokers' reactions to reduced ignition propensity cigarettes. Tobacco Contr 15:45-49

O'Connor RJ, Rees VW, Norton KJ, Cummings KM, Connolly GN, Alpert HR et al (2010) Does switching to reduced ignition propensity cigarettes alter smoking behaviour or exposure tobacco smoke constituents? Nicotine Tob Res 12:1011-1018

Paul KT (2000) Assessment of cigarettes of reduced ignition power and their role to reduce fire risks of upholstered seating, mattresses and bed assemblies. J Fire Sci 18:28-73

Pauly JL, O'Connor RJ, Paszkiewicz GM, Cummings KM, Djordjevic MV, Shields PG (2009) Cigarette filter-based assays as proxies for toxicant exposure and smoking behaviour-a literature review. Cancer Epidemiol Biomarkers Prev 18:3321-3333

Piadé JJ, Wajrock S, Jaccard G, Janeke G (2013) Formation of mainstream cigarette smoke constituents prioritized by the World Health Organization Yield patterns observed in market surveys, clustering and inverse correlations. Food Chem Toxicol 55:329-347

Rein G (2009) Smouldering combustion phenomena in science and technology. Int Rev Chem Eng 1:3-18

Robinson DP, Reynard JR, Baker RR (1992) Preliminary feasibility study on the application of cone calorimetry to measure cigarette ignition propensity, Proceedings of CORESTA Congress. Technology Group, Jerez de la Frontera, pp 74-81

Ruegg R, Petraglia L (2005) Impact assessment of New York State's cigarette Fire safety performance standard. NIST GCR 05-882. Gaithersburg, MD, USA: NIST

Saidi MS, Mhaisekar A, Hajaligol MR, Subbiah M (2006) Effects of thermo-physical and flow parameters on the static and dynamic burning of a cigarette. Combust Theor Model 10:939-960 
Salig R (1982) The Smoldering Behavior of Upholstered Polyurethane Cushionings and its Relevance to Home Furnishings Fires, Master's Thesis, Massachusetts Institute of Technology, Cambridge, MA

Seaman S (1933) Decreasing inflammability of cigarettes. US patent no. 1,996,002, 25 March

Seidenberg AB, Rees VW, Alpert HR, O'Connor RJ, Connolly GN (2011) Ignition strength of 25 international cigarette brands. Tob Contr 20:77-80

Sherwood TS, Issac JC, Murthi RM, Wiedemann KE, Janardhan S, Jones JS (2006) Semi-empirical model using radiant coal power to predict cigarette ignition strength as measured by extinction test. Fire Technol 42:233-251

Singh H, Jain AK (2009) Ignition, combustion, toxicity and fire retardancy of polyurethane foams: a comprehensive review. J Applied Polymer Sci 111:1115-1143

Spears AW, Rhyne AL, Norman V (1995) Factors for consideration in a test for cigarette ignition propensity on soft furnishings. J Fire Sci 13:59-84

State of California Department of Consumer Affairs (2014) TECHNICAL BULLETIN 117-2013. Requirements, Test Procedure and Apparatus for Testing the Smolder Resistance of Materials Used in Upholstered Furniture

Theophilus EH, Pence DH, Meckley DR, Shreve WK, Ayres PH, Bombick RB, Borgerding MF, Garner CD (2007a) Toxicological evaluation of cigarettes with two banded cigarette paper technologies. Exp Toxicol Pathol 59:17-27

Theophilus EH, Shreve WK, Ayres PH, Garner CD, Pence DH, Swauger JE (2007b) Comparative 13-week cigarette smoke inhalation study in Sprague-Dawley rats: Evaluation of cigarettes with two banded cigarette paper technologies Food Chem Toxicol 45:1076-1090

Timmis MR (2007) Cigarette ignition as a source of fatal fires: examining the case for reduced ignition propensity cigarettes in the United Kingdom, M. Sc Thesis, Anglia Ruskin University

Wanna JT, Jupe R, Chen PL, Greear LA (1996) Effect of cotton duck \#6 inter-bolt variability on cigarette ignition propensity test outcome. J Fire Sci 14:313-324

Wanna JT, Zelius P (2001) Effect of cigarette variables on ignition propensity of various fabrics. J Fire Sci 19:341-354

Wanna JT, Chen PX (2001) Cigarette ignition performance. J Fire Sci 9:355-368

Watkins ML, Jones JS (2001) Characterization of the heat transfer for cigarette ignition propensity substrate using transient thermal analysis. CORESTA Smoke and Technology Meeting, Xian, Paper ST28

Watkins ML, Lyons-Hart JL, Murthi RMV (2001) The thermal performance of banded paper cigarettes. CORESTA Smoke and Technology Meeting, Xian, Paper ST29

Watkins ML, Lyons-Hart JL, Axelson D (2001) Dynamic characterization of banded paper cigarettes using Fourier transformed infrared (FTIR) spectroscopy and nuclear magenetic resonance (NMR) imaging techniques. CORESTA Smoke and Technology Meeting, Xian, Paper ST30

Waymack BE, Kellog DS, McRae DD, Dwyer RW (1997) Watts in a cigarette: Thermophysical properties of smoldering cigarettes. Tob Sci 41:74-81

Werley MS, Jerome AM, DeSoi DJ, Coggins CRE, Oldham MJ, McKinney WJ (2013) A comprehensive evaluation of the toxicology of experimental cigarettes manufactured with banded papers. Inhal Toxicol 25:19-33

Williams FA (1976) Mechanism of fire spread. In: Proceedings of the Sixteenth Symposium (International) on Combustion. The Combustion Institute, Pittsburgh, pp 1281-1294

Wu E-C, Ihrig AM, Norman V (1992) Ignition propensity testing at different $\mathrm{O}_{2}$ concentrations. J Fire Sci 10:365-85

Yi SC, Song ES, Oh SG, Bae SY, Moon SK, Hajaligol MR (2001) Theoretical analysis of the effects of cigarette design parameters on the smouldering rates, heat flux, and total heat released during smouldering of a cigarette. J Fire Sci 19:18-30

Yea K-N (1985) Ignition risk analysis-cigarette ignition of upholstered furniture. Fire Tech 21:105-121

Yau RK, Marshall SW (2014) Association between fire-safe cigarette legislation and residential fire deaths in the United States. Injury Epidemiolo 1:1-6

Zheng Z, Gu W, Zhang J, Liu B (2006) Influence of cigarette smoking parameters on the burning temperature and delivery levels of some smoke constituents. $60^{\text {th }}$ Tobacco Science Research Conference, Montreal, Canada, Paper 76

\section{Submit your manuscript to a SpringerOpen ${ }^{\circ}$ journal and benefit from:}

- Convenient online submission

- Rigorous peer review

- Immediate publication on acceptance

- Open access: articles freely available online

- High visibility within the field

- Retaining the copyright to your article

Submit your next manuscript at $\gg$ springeropen.com 